but if this be the case, two years seems a too generous allowance of time to be occupied in passage through the press, to the exclusion of belated additions, even in the case of an elaborate monograph such as that under review. The volume of text concludes with a full and wellplanned index, while there is the useful luxury of a second index at the end of the volume of plates.

Special praise must be accorded to the plates, upwards of roo in number, which illustrate this work. These are well reproduced in collotype process from beautifully executed drawings, mainly by Miss Frances Wieser, of the United States Geological Survey. The careful and detailed work of the artist is a fine achievement. To many who have little acquaintance with the Cambrian brachiopods beyond the scanty assemblage found in our own country, the perusal of this volume of plates will prove a revelation. It is indeed astonishing to find that such a profusion of species had been evolved and such elaborate specialisation had been attained by many of them in those remote ages. One can only picture in imagination the long and slowly evolving lines of precursors of which no trace has yet been found.

Dr. Walcott deserves the warmest thanks of all palæontologists and geologists for a treatise which must long remain a classic. The public department which has issued the work in such handsome form is also to be congratulated. What higher service can such a department perform than thus to give practical encouragement to arduous scientific labour?

F. L. K.

\section{THE TRANSMISSION OF PLAGUE BY FLEAS.}

THE third Plague Supplement of the Journal of Hygiene maintains the high standard both of research and of editing set by the previous numbers. It contains eight good articles, chiefly by S. Rowland and R. St. John Brooks, on the bacteriology of plague and by A. W. Bacot on the rat flea. 'The former articles deal with the influence of cultivation in serum-containing media upon the virulence and immunising properties of the plague bacillus; upon the facility with which it is ingested by human leucocytes; and upon its virulence-all points of importance in regard to bacteriology in general. Mr. Bacot's most laborious and well-set-out researches upon the influence of temperature and humidity upon the pathophores and on the effect of vapours as insecticides deserve much commendation; but perhaps the most interesting article is by him and Prof. C. J. Martin on the mechanism and transmission of plague by fleas. They sum up a very careful paper by the following remarks :-

"Under conditions precluding the possibility of infection by dejecta it was found that two species of rat fleas, Xenopsylla cheopis and Ceratophyllus fasciatus, fed upon septicæmic blood, can transmit plague during the act of sucking, and that certain individuals suffering from a temporary obstruction at the entrance to the stomach were responsible for most of the infections obtained, and probably for all. In a proportion of infected fleas the development of the bacilli was found to take place to such an extent as to occlude the alimentary canal at the entrance to the stomach. The culture of pest appears to start in the intercellular recesses of the proventriculus, and grows so abundantly as to choke this organ and extend into the œsophagus. Fleas in this condition are not prevented from sucking blood as the pump is in the pharynx, but they only succeed in distending an already contaminated œsophagus, and, on the cessation of the pumping act, some of the blood is forced back into the wound. Such fleas are persistent in their endeavours to feed, and this renders them particularly dangerous."

R. R.

\section{NOTES.}

WE announce with deep regret the death on March I6, as the result of a motor accident, of Sir John Murray, K.C.B., F.R.S., the distinguished naturalist and oceanographer.

ThE Right Hon. Sir Francis Hopwood has been appointed by the president and council of the Royal Society to a seat on the general board and executive committee of the National Physical Laboratory, in succession to Sir Arthur Rücker, F.R.S., resigned.

WE notice with regret a Reuter message from New York reporting the death on March I6 of Prof. E. S. Holden, director of the Lick Observatory from 1888 to 1898 , and author of a number of papers and other works on astronomical subjects.

THE death is announced, on March 7, at seventythree years of age, of Prof. Antonino Salinas, professor of archæology at the University of Palermo and director of the Archæological Museum.

Prof. J. G. ADAmi, F.R.S., Strathcona professor of pathology and bacteriology, McGill University, Montreal, has been awarded the Fothergill gold medal of the Medical Society of London for 1914, for his work on pathology and its application to practical medicine and surgery.

THE death is announced, in his sixty-seventh year, of Dr. E. J. Houston, one of the inventors of the Thomson-Houston system of arc lighting. He was twice elected president of the American Institute of Electrical Engineers, and was the author of more than fifty books, mainly on electricity and allied subjects.

Prof. F. Keeble, F.R.S., professor of botany, University College, Reading, has been appointed director of the Royal Horticultural Society's garden at Wisley, with the view of making it of more general practical service. $\mathrm{Mr}$. F. Chittenden will remain in charge of the educational section, and Mr. S. T. Wright will continue to act as superintendent of the garden.

Miss A. Cannon, whose critical examination of Harvard College Observatory photographs has led her to the discovery of many new variable stars and other objects of interest, has been elected an honorary memพо. 23 I6, VoL. 93] 